\title{
Performance Benchmarking in Turkish Food and Beverage Industry
}

\author{
Arzu Tektas and Esin Ozdemir Tosun \\ Bogazici University, Hisar Campus 34342, Istanbul, Turkey
}

\begin{abstract}
As the competition in the business world shifts from organizational to supply chain level and consequently include multi dimensions such as cost, quality and speed; efficiency and benchmarking analyses of supply chains require special attention. Within this context, this paper benchmarks the performance of Turkish food and beverage companies and discusses their global competitiveness as well as the improvement opportunities. Namely, it purposes to search for strengths and weaknesses at company level as well as opportunities and threats at the industry level. The methodology involves the data envelopment analysis (DEA) approach and related sensitivity analyses. Results illustrate that export increases supply chain efficiency scores of most companies, supporting some previous studies which show export as an indirect channel to increase productivity. Although Turkish food and beverage companies utilize a limited amount of their resources to generate export revenues and don't realize high export volumes, they seem to use their export strategies wisely and benefit from exports to a certain extent. Results also demonstrate that these companies can generate revenues but cannot utilize their resources and the related supply chains effectively to generate sufficient profits. Increasing the profit level might require more efficiently managed supply chains.
\end{abstract}

Keywords: Supply chain management, data envelopment analysis, benchmarking, efficiency, Turkey

\section{Introduction}

Efficiency of supply chain systems has been a critical issue in today's business world where the competition has shifted from organizational level to supply chain level (Ragu-Nathan et al., 2006). As the global trade environment became more competitive, global competition forced companies to compete on multi dimensions like cost, quality, speed; consequently, efficiency of their supply chains emerged as a significant competitive advantage. Performance benchmarking has become indispensable for companies to further their improvement and stay competitive. Within this context, this paper benchmarks the performance of Turkish food and beverage companies via data envelopment analysis (DEA) and discusses their global competitiveness as well as the improvement opportunities. This might purpose to search for strengths and weaknesses at company level as well as opportunities and threats at the industry level including the international arena.

\section{Performance benchmarking in supply chains}

Performance benchmarking analyzes a company's efficiency in comparison to its competitors by identifying the most efficient companies and ranking the remaining companies referring to the efficient ones (Goncharuck, 2008). Literature contains various studies regarding supply chain (SC) performance benchmarking and its effects on company success. Reiner and Hofmann (2006) show that efficient chains lead to high financial performance. Tan et al. (2002) (as cited in Basnet et al., 2003) show a significant correlation between certain SC practices and firm performances. Narasimhan et al. (2006) show that an effective SC can

Copyright (c) 2010 Arzu Tektas and Esin Ozdemir Tosun This is an open access article distributed under the Creative Commons Attribution License unported 3.0, which permits unrestricted use, distribution, and reproduction in any medium, provided that original work is properly cited. Contact Author: Arzu Tektas e-mail: tektas@boun.edu.tr 
significantly affect profitability. D'avonzo et al. (2003) find a strong connection between superior SC performance and financial status such as high shareholder values and high market capitalization rates. Ellram and Liu (2002) state that shareholder value can be lost because of poor SC management. The study of Singhal and Hendricks (2002) shows how SC glitches can have a significant negative effect on shareholder value regardless of company size or industry. As these studies imply, an efficiently managed supply chain can be a crucial factor in a company's financial strength and success in the market.

Although supply chain management is a relatively new concept in business literature, there have been shifts in research focus. Cost based performance measures are the main concern of early literature. Beamon (1999) presents Cohen and Moon (1990), Lee and Feitzinger (1995) and Pyke and Cohen (1993) as some of the authors that used cost based performance measures in their supply chain models. These measures generally include costs of goods sold, inventory costs and operating costs. In later studies, the importance and need for qualitative measures as well as other quantitative measures are realized and measures such as quality (Chan, 2003), customer satisfaction (Gunasekaran et al, 2001) and risk management (Johnson and Randolph, 1995 as cited in Beamon, 1999) come into the picture. Beamon (1999) groups SC performance measures into three as resource, output and flexibility. Chan (2003) identifies seven SC performance measures and categorizes them as quantitative (cost and resource utilization) and qualitative (quality, flexibility, visibility, trust, and innovativeness).

Literature contains various applications that benchmark SC performances at sector or product group level. Reiner and Hofmann (2006) benchmark 65 European and American companies from different industries. They specify the number of fulltime employees in production, total inventory costs, supply chain costs, ship from locations (tier 1 suppliers), ship to locations (tier 1 customers), number of warehouse locations as input variables; revenue and delivery performance rate as output variables. They conclude that efficient supply chains lead to high financial performance and emphasize the benefits of warehouse pooling. Wong and Wong (2007) use revenue and on time delivery rate as output variables; supply chain costs, cycle time and manufacturing capacity as input variables. They find that the opportunity cost (profit loss) calculated by the model serves as a good reference to managers to make efficient decisions on resource allocations.

Frameworks are also proposed regarding integrated supply chains which is a major concern of SCM today (Gunasekeran et al., 2004; Angerhofer and Angelide, 2006; Agarwal et al., 2006; Molnar et al, 2007). Many authors (Wong and Wong, 2007, Liang et al., 2006, Qu et al., 2006, Beamon, 1999, Gunasekaran et al., 2001) mention the importance of performance evaluation for all members of a supply chain in order to increase customer satisfaction. However, some studies are considered inapplicable since even leading companies do not have such data sets and measurement systems for their entire supply chains (Ross, 1998). Shah and Singh (2001) overcome data problems by defining a SC inefficiency ratio which only requires publicly available data. Ulus et al. (2006) present a benchmarking study of industrial transportation companies traded in the NYSE by using solely publicly available data to conduct a financial performance analysis. They find significant performance differences among the sub-sectors of the transportation industry.

Within the context discussed above, the paper proceeds with benchmarking the performance of Turkish food and beverage companies.

\section{Methodology}

Turkish food and beverage companies are benchmarked using data envelopment analysis (DEA). The analysis identifies the best practice supply chains as well as the inefficient ones and their causes. Target units are specified for each inefficient unit 
for further improvement and suggestions are made for adaptations. A further discussion related to the choice of DEA can be found in Ozdemir (2009).

DEA is a non-parametric linear model developed by Charnes, Cooper, and Rhodes (1978) to evaluate the relative efficiencies of similar decision making units (DMU) by considering multiple inputs and outputs simultaneously. Within DEA context, the efficiency of any DMU is the maximum of a ratio of weighted outputs to weighted inputs subject to the limitation of the similar ratios for every DMU be less than or equal to one. The most efficient DMUs score 1 and the relatively inefficient ones less than 1.

The basic CCR model of DEA is formulated as follows

$$
\begin{aligned}
& \max h_{0}(u, v)=\frac{\sum_{r} u_{r} y_{r o}}{\sum_{i} v_{i} x_{i o}} \\
& \text { subject to: } \\
& \frac{\sum_{r} u_{r} y_{r j}}{\sum_{i} v_{i} x_{i j}} \leq 1 ; j=1, \ldots, n, \\
& u_{r}, v_{i} \geq 0 \text { for all } \mathrm{i} \text { and } \mathrm{r}
\end{aligned}
$$

where:

$\mathrm{h}_{0}$ : the efficiency value that maximizes the ratio of $\mathrm{DMU}_{0}$. $\mathrm{v}_{\mathrm{i}}$ : weight for input $\mathrm{i}$ $\mathrm{u}_{\mathrm{r}}$ : weight for output $\mathrm{r}$ $\mathrm{x}_{\mathrm{i} 0}$ : observed value for input $\mathrm{x}$ of $\mathrm{DMU}_{\mathrm{o}}$ $\mathrm{y}_{\mathrm{ro}}$ : observed value for output $\mathrm{y}$ of $\mathrm{DMU}_{\mathrm{o}}$ $\mathrm{n}$ : the number of DMUs

The above non-linear model can be converted to a linear one with weights indicated as $(\mu, v)$.

$$
\begin{aligned}
& \max z=\sum_{r=1}^{s} \mu_{r} y_{r o} \\
& \sum_{r=1}^{s} \mu_{r} y_{r j}-\sum_{i=1}^{m} v_{i} x_{i j} \leq 0 \\
& \sum_{i=1}^{m} v_{i} x_{i o}=1 \\
& \mu_{r}, v_{i} \geq 0
\end{aligned}
$$

In order to obtain the relative efficiency score of each DMU, this linear model is run for each DMU and the related maximum efficiency score is calculated by determining the optimal weights of $\mu$ and $v$.

\section{Input and output measures}

Referring to the related literature discussed in this paper, supply chain cost, total inventory and full-time employee number are defined as input and revenue is defined as output variables to evaluate SC performances at company level utilizing DEA. Regarding their possible effects on operational performance, profit and export are also included consequently as output measures.

Supply chain cost is related with the costs of operations within the chain. It includes the distribution costs and inventory holding costs as in Shah and Singh (2001). Cost of capital is used as the inventory carrying cost for practical purposes. Related data for Turkish food and beverage companies is acquired from Ege and Bayraktaroglu (2008). Similarly, due to data limitations, distribution cost data is replaced with marketing and selling costs since distribution costs are a significant and usually a proportional percentage of this expenditure. Validity of this replacement is verified by conducting phone interviews with three logistics managers in food and beverage industry.

Revenue is considered as the major output variable since it indicates how well the company performs its operations and controls its SC. High revenue might indicate the company's success in the market-place; however, it does not necessitate making high profits. A company with high revenues might lack effective operations management; which would increase costs of goods sold and decrease profit.

On the other hand, export is a strategy that affects company operations and SC designs. Companies export to expand their customer portfolios, learn from global competitors, catch up with rapid global trends and increase their revenues. Helpman et al (2004); Bernard et al., (2003) and Melitz (2003) argue that companies with efficient operations tend to export. Consequently, export might be an 
indicator of good operations performance and effectively managed supply chains. If a company's SC performs well, then its products and services are expected to be better quality and lower cost creating higher customer satisfaction and increasing the chance of success in the global arena. For a supplier to compete in the export market, Piercy et al. (1998) list some SC related specifications like cost per unit production, cost of goods sold, selling price to end-user abroad, product quality, product accessibility, delivery speed and reliability. Zou and Stan (1998) conclude that low cost can significantly impact export performance and Ling-Yee and Ogunmokun (2001) state that exporting companies should improve SC management skills for success.

Literature cites only a few studies (Duzakin and Duzakin, 2007) that measure the financial performance of manufacturing firms in the DEA context using profit and export variables along with revenue. As a result, considering profit, revenue and export among performance measures will contribute to this study as well as the literature.

\section{Analysis of the Turkish food and beverage industry}

The food and beverage industry experiences a high level of competition where effective management strategies in company supply chains are critical for being competitive. Miller and Roth (1994) state that food manufacturers' competition is based on infrastructural changes in manufacturing operations which will cut costs and improve quality. This can be achieved through efficient use of resources and efficient management of supply chains.

Food and beverage sector is among the first industries established in Turkey. Turkey has certain competitive advantages in agricultural production (Istanbul Ticaret Odası [ITO], 2006); however, cannot benefit from this in the global arena (TUSIAD, 2007). Turkey's annual agricultural and live animal exports data indicate the need of foreign markets for these products as raw materials. However,
Turkey is not strong at transforming these raw materials into processed products that would have higher value added. Researches on this area (TUSIAD, 2007, ITO, 2006) suggest the implementation of effective management strategies to overcome the existing problems between suppliers and manufacturers, to increase capacity utilization and to decrease production costs. Turkish companies should give importance to supply chain management which can decrease cost of production, improve supplier-customer relations and create high level of customer satisfaction.

This study analyzes the supply chains of Turkish food and beverage companies to observe their performance efficiencies in the domestic market in terms of their profit, revenue and export generating status. The study of Salomon and Shaver (2005) is a motivation to conduct this analysis. Analyzing Spanish domestic companies, they find that export and domestic sales are complements; moreover, the strength in the domestic market drives export sales. To enter foreign markets and increase exports, companies have to strengthen their positions in their domestic markets. Benchmarking would give companies the opportunity to analyze their strengths and weaknesses in the market. Furthermore, observing, comparing and adjusting the operations of the outperforming domestic competitors may improve and strengthen the value generating capability and the export revenues of the inefficiently managed companies and the industry.

\section{Results}

Turkish food and beverage companies are benchmarked using DEA. The models are executed utilizing computer facilities and the Solver Pro software. Data set includes the food and beverage companies traded in the Istanbul Stock Exchange (ISE) thus, data availability and reliability problems are minimized. Omitting one company due to its hybrid operations, results in 23 companies. Data is collected via internet from ISE and companies' websites for the year 2007. For confidentiality purposes, companies are named as TR1, TR2 etc. 
The analyses include a basic run and six additional runs for sensitivity analysis. The input variables are SCM costs, total inventory and full-time employee number. Output variables used in each run vary among revenue, profit and export (Table 1). Sensitivity analyses are performed to observe how revenue, profit and exports affect the supply chain efficiency of companies.

Table 1 presents the results of the basic run along with the sensitivity analyses performed.

Table 1. Sensitivity analysis results

\begin{tabular}{|l|l|l|l|l|l|l|l|}
\hline & \multicolumn{7}{|c|}{ List of runs with different output variables } \\
\hline & RUN 1 & RUN 2 & RUN 3 & RUN 4 & RUN 5 & RUN 6 & $\begin{array}{l}\text { BASIC } \\
\text { RUN }\end{array}$ \\
\hline & & & & & & & \\
Output & & & & & & \\
vrbls & $\begin{array}{l}\text { export } \\
\text { DMU }\end{array}$ & $\begin{array}{l}\text { export } \\
\text { profit }\end{array}$ & $\begin{array}{l}\text { revenue } \\
\text { profit }\end{array}$ & $\begin{array}{l}\text { export } \\
\text { revenue }\end{array}$ & export & profit & revenue \\
\hline TR 1 & $\mathbf{1 . 0 0}$ & $\mathbf{1 . 0 0}$ & 0.61 & $\mathbf{1 . 0 0}$ & $\mathbf{1 . 0 0}$ & 0.61 & 0.53 \\
\hline TR 2 & $\mathbf{1 . 0 0}$ & 0.94 & $\mathbf{1 . 0 0}$ & $\mathbf{1 . 0 0}$ & 0.90 & $<0.01$ & $\mathbf{1 . 0 0}$ \\
\hline TR 3 & 0.40 & 0.05 & 0.40 & 0.40 & 0.01 & 0.05 & 0.40 \\
\hline TR 4 & $\mathbf{1 . 0 0}$ & $\mathbf{1 . 0 0}$ & 0.19 & $\mathbf{1 . 0 0}$ & $\mathbf{1 . 0 0}$ & $<0.01$ & 0.19 \\
\hline TR 5 & 0.31 & 0.31 & 0.28 & 0.28 & 0.08 & 0.28 & 0.26 \\
\hline TR 6 & $\mathbf{1 . 0 0}$ & $\mathbf{1 . 0 0}$ & 0.48 & $\mathbf{1 . 0 0}$ & $\mathbf{1 . 0 0}$ & $<0.01$ & 0.48 \\
\hline TR 7 & $\mathbf{1 . 0 0}$ & $\mathbf{1 . 0 0}$ & $\mathbf{1 . 0 0}$ & $\mathbf{1 . 0 0}$ & 0.06 & $\mathbf{1 . 0 0}$ & $\mathbf{1 . 0 0}$ \\
\hline TR 8 & $\mathbf{1 . 0 0}$ & $\mathbf{1 . 0 0}$ & $\mathbf{1 . 0 0}$ & 0.76 & 0.39 & $\mathbf{1 . 0 0}$ & 0.70 \\
\hline TR 9 & $\mathbf{1 . 0 0}$ & $\mathbf{1 . 0 0}$ & $\mathbf{1 . 0 0}$ & $\mathbf{1 . 0 0}$ & 0.65 & $\mathbf{1 . 0 0}$ & $\mathbf{1 . 0 0}$ \\
\hline TR 10 & $\mathbf{1 . 0 0}$ & 0.84 & 0.76 & $\mathbf{1 . 0 0}$ & 0.70 & 0.57 & 0.76 \\
\hline TR 11 & 0.97 & 0.10 & 0.97 & 0.97 & $<0.01$ & 0.10 & 0.97 \\
\hline TR 12 & 0.94 & 0.74 & 0.94 & 0.76 & 0.05 & 0.74 & 0.76 \\
\hline TR 13 & 0.85 & 0.23 & 0.85 & 0.85 & 0.22 & $<0.01$ & 0.85 \\
\hline TR 14 & 0.77 & 0.56 & 0.61 & 0.77 & 0.51 & 0.18 & 0.61 \\
\hline TR 15 & $\mathbf{1 . 0 0}$ & 0.81 & 0.78 & $\mathbf{1 . 0 0}$ & 0.61 & 0.58 & 0.78 \\
\hline TR 16 & 0.74 & 0.21 & 0.74 & 0.74 & 0.21 & $<0.01$ & 0.74 \\
\hline TR 17 & 0.66 & 0.64 & 0.26 & 0.61 & 0.61 & 0.02 & 0.26 \\
\hline TR 18 & $\mathbf{1 . 0 0}$ & $\mathbf{1 . 0 0}$ & 0.67 & 0.95 & 0.85 & 0.67 & 0.56 \\
\hline TR 19 & 0.69 & 0.69 & 0.28 & 0.63 & 0.63 & 0.00 & 0.28 \\
\hline TR 20 & 0.97 & 0.97 & 0.29 & 0.97 & 0.97 & $<0.01$ & 0.29 \\
\hline TR 21 & 0.55 & 0.53 & 0.54 & 0.55 & 0.06 & 0.53 & 0.54 \\
\hline TR 22 & 0.90 & 0.90 & 0.43 & 0.90 & 0.90 & 0.16 & 0.43 \\
\hline TR 23 & $\mathbf{1 . 0 0}$ & 0.89 & $\mathbf{1 . 0 0}$ & $\mathbf{1 . 0 0}$ & 0.89 & $<0.01$ & $\mathbf{1 . 0 0}$ \\
\hline
\end{tabular}

The results in Table 1 show that no DMU is efficient in all combinations, which may imply that resources are not utilized totally efficiently. Supply chains of TR 7 and TR 9 are efficient in all combinations except when only export is taken as the output variable. Actually, these two companies are not export oriented and the percentage of exports in their revenue is $1 \%$ and $7 \%$ respectively.
Results depict that DMU efficiency scores increase or at least remain the same when export is included as an output variable. This is apparent in comparing Run 3 and Run 1; Run 6 and Run 2; Basic Run and Run 4. Although Turkish food and beverage companies are not utilizing a majority of their resources to generate export revenues, they seem to use their export strategies wisely and benefit from exports to a certain extent. 
Profit is also found to be a significant variable in explaining supply chain and hence financial efficiencies of companies. When profit and revenue are taken as output variables (Run 3), the efficiency scores of TR1, TR5 TR8, TR12 and TR18 increase and the rest (18 companies) remain the same in comparison to the efficiency scores of the Basic Run. Seven companies realize losses, and three of them become efficient when revenue is the only output variable. Adding profit to output variables cannot increase the efficiency scores of these seven companies.
When profit is used along with export and revenue in outputs, the efficiency scores of six companies increase in comparison to the run where export and revenue are used. The increases in supply chain efficiency may mean that these companies are utilizing their revenues to make profit.

Results of the Basic Run are also analyzed to assess each input and output variable's contribution to DMU's efficiency score. The related results are tabulated in Table 2.

Table 2. Contributions of the variables to efficiency scores

\begin{tabular}{|l|l|l|l|l|l|l|}
\hline DMU & Employee & Inventory & SCM & Revenue & Export & Profit \\
\hline TR 1 & 0.62 & 0.38 & 0 & 0 & 1 & 0 \\
\hline TR 2 & 1 & 0 & 0 & 1 & 0 & 0 \\
\hline TR 3 & 2.47 & 0 & 0.06 & 1 & 0 & 0 \\
\hline TR 4 & 0 & 0.12 & 0.88 & 0.07 & 0.93 & 0 \\
\hline TR 5 & 0.58 & 1.72 & 0.98 & 0 & 0.15 & 0.85 \\
\hline TR 6 & 1 & 0 & 0 & 0.06 & 0.94 & 0 \\
\hline TR 7 & 0.75 & 0.25 & 0 & 1.00 & 0 & 0 \\
\hline TR 8 & 0 & 0.86 & 0.14 & 0.57 & 0.21 & 0.21 \\
\hline TR 9 & 0.70 & 0.30 & 0 & 1 & 0 & 0 \\
\hline TR 10 & 0.21 & 0.79 & 0 & 0.65 & 0.35 & 0 \\
\hline TR 11 & 0.96 & 0 & 0.07 & 1 & 0 & 0 \\
\hline TR 12 & 0 & 1.07 & 0 & 0.87 & 0 & 0.12 \\
\hline TR 13 & 1.13 & 0 & 0.05 & 1 & 0 & 0 \\
\hline TR 14 & 1.15 & 0 & 0.16 & 0.63 & 0.37 & 0 \\
\hline TR 15 & 0.56 & 0.44 & 0 & 0.76 & 0.24 & 0 \\
\hline TR 16 & 0.61 & 0.75 & 0 & 0.89 & 0.11 & 0 \\
\hline TR 17 & 0 & 1.05 & 0.47 & 0.25 & 0.75 & 0.005 \\
\hline TR 18 & 1 & 0 & 0 & 0 & 0.89 & 0.11 \\
\hline TR 19 & 0.97 & 0.13 & 0.35 & 0 & 1 & 0.01 \\
\hline TR 20 & 1.04 & 0 & 0 & 0 & 1 & 0 \\
\hline TR 21 & 1.37 & 0.48 & 0 & 1 & 0 & 0 \\
\hline TR 22 & 0.00 & 0.77 & 0.34 & 0 & 1 & 0 \\
\hline TR 23 & 0 & 0.06 & 0.94 & 0.39 & 0.61 & 0 \\
\hline
\end{tabular}

The table demonstrates that the contribution of some variables to the efficiency score is zero for some DMUs. Profit variable doesn't contribute to the scores of 17 DMUs out of 23. The explanation might be that their profits remain relatively low compared to their total revenues or export revenues; therefore, DEA assigns zero weight to their profit variable to maximize the efficiency scores of these DMUs. SCM cost variable of 11 companies are also assigned zero weight which may indicate that SCM costs are higher than other operations costs such as inventory and employees. The minimum number of zero weights is assigned to the variables of revenue and full time employee number. Revenue seems to be the outcome that compensates the inefficiencies in other outputs of the 
companies. As the variable with the least zero weight assigned, full-time employee number seems to be the most wisely utilized resource. This outcome is also supported when the value of weights assigned are compared. The highest value is given to the variable, number of full-time employees. Considering eight zero weights assigned to the inventory variable, it may be said that Turkish companies learn to benefit from inventory management strategies of supply chain such as inventory pooling. Seven zero values in export variables might depict that the Turkish food and beverage companies seem to benefit from their exporting activities to a certain extent.

Table 3. Slack variables of DMUs calculated by DEA

\begin{tabular}{|l|l|l|l|l|l|l|}
\hline & \% Excess & \% Excess & \% Excess & \% Shortage & \% Shortage & \% Shortage \\
\hline DMU & Employee & Inventory & SCM & Revenue & Export & Profit \\
\hline TR 3 & 0 & 40.12 & 0 & 152.92 & 999.90 & 999.90 \\
\hline TR 5 & 0 & 0 & 0 & 233.15 & 227.10 & 227.10 \\
\hline TR 11 & 0 & 73.34 & 0 & 2.82 & 999.90 & 700.63 \\
\hline TR 12 & 57.89 & 0 & 31.24 & 6.50 & 70.03 & 6.50 \\
\hline TR 13 & 0 & 40.47 & 0 & 18.05 & 56.63 & 999.90 \\
\hline TR 14 & 0 & 60.27 & 0 & 30.68 & 30.68 & 72.51 \\
\hline TR 16 & 0 & 0 & 48.57 & 35.55 & 35.55 & 999.90 \\
\hline TR 17 & 55.55 & 0 & 0 & 52.00 & 52.00 & 52.00 \\
\hline TR 19 & 0 & 0 & 0 & 110.15 & 45.36 & 45.36 \\
\hline TR 20 & 0 & 73.20 & 28.25 & 67.74 & 3.55 & 94.36 \\
\hline TR 21 & 0 & 0 & 0 & 83.06 & 83.06 & 87.57 \\
\hline TR 22 & 6.84 & 0 & 0 & 14.34 & 10.86 & 119.78 \\
\hline
\end{tabular}

Similar conclusions about profit can also be reached by analyzing Table 3 which presents input excesses and output shortfalls of each inefficient DMU. It is observed that 23 DMUs have an average of $35 \%$ revenue shortage whereas $192 \%$ profit shortage. This result also support the idea that Turkish food and beverage companies can generate revenues but cannot utilize their resources and the related SCs to generate sufficient profits. They need to decrease costs to increase their profits which require more efficiently managed supply chains which can be achieved by inventory management, efficient resource utilization, distribution network configuration as well as establishing strategic partnerships with suppliers and customers.

Average shortage level of $114 \%$ in export revenues (Table 3) may imply that Turkish food and beverage companies do not realize enough exports. Increase in their export activities will increase capacity utilization, decrease idle capacity costs, increase company revenue and profit which will help to increase the overall efficiency of Turkish companies.

Results of the output oriented DEA model (Table 3) demonstrate that the average input excess levels are relatively low with respect to the averages of output shortages. DMUs have an average excess of $5.2 \%$ in number of employees, $0.5 \%$ in SCM costs and $12.5 \%$ in total inventory. Inputs excesses affect supply chain performances negatively (Duzakin and Duzakin, 2007). As the costs of goods sold increase, the profits decrease. These factors might hinder the value generation capabilities of companies. Value generation is the ultimate aim of SCM. Generating insufficient value due to inefficient management strategies and high operations costs would decrease supply chain efficiencies.

\section{Conclusion}

This study benchmarks the supply chain performances of Turkish food and beverage companies via data envelopment analysis (DEA) and discusses their global 
competitiveness as well as the improvement opportunities. This might purpose to search for strengths and weaknesses at company level as well as opportunities and threats at the industry level including the international arena. The selected methodology and the implementation results may aid future benchmarking analyses and draw attention to the possibility of supply chain benchmarking with only publicly available data.

Considering the input output measures of the study, the output variables are extended to include profit and export besides revenue. Export is observed to increase supply chain efficiency scores of a high number of companies. Findings support Greenaway, Sousa and Wakelin (2004) who show that export is an indirect channel to increase productivity. Although Turkish food and beverage companies utilize a limited amount of their resources to generate export revenues and don't realize high export volumes, they seem to use their export strategies wisely and benefit from exports to a certain extent. Results also demonstrate that these companies can generate revenues but cannot utilize their resources and the related SCs effectively to generate sufficient profits. Increasing the profit level might require more efficiently managed supply chains.

The study can be extended two folds. The developed methodology and the measurement set can be applied to all the companies traded in ISE with the accompanying sensitivity analyses in order to evaluate supply chain efficiencies of different sectors in Turkey. A longitudinal study can be conducted utilizing Malmquist index with publicly available data at company and industry level. This implementation would make it easier and more comprehensive to relate the changes in supply chain efficiencies to macro criteria such as international trade.

\section{References}

Agarwal, A. Shankar, R. and Tiwari, M. K. (2006), "Modeling the Metrics of Lean, Agile and Leagile Supply Chain: An ANPBased Approach," European Journal of Operational Research, 173, 211-225.

Angerhofer, B. J. and Angelides, M. C. (2006), "A Model and a Performance Measurement System for Collaborative Supply Chains," Decision Support Systems, 42, 283-301.

Basnet, C. Corner, J. Wisner J. and Tan K. C. (2003), "Benchmarking Supply Chain Management Practice in New Zealand," Supply Chain Management: An International Journal, 8, 57-64.

Bernard, A.B. Eaton, J. Jensen, J. B. and Kortum, S.S. (2003), "Plants and Productivity in International Trade," American Economic Review, 93, 1268-1290.

Chan, F. T. S. (2003), "Performance Measurement in a Supply Chain," International Journal of Advanced Manufacturing Technology, 21, 534-548.

Charnes, A. Cooper, W. and Rhodes, E. (1978), "Measuring the Efficiency of Decision Making Units," European Journal of Operational Research, 2, 429-44.

Chopra, S. and Meindl, P. (2007), Supply Chain Management: Strategy, Planning, Operation, 3rd Edition, Englewood Cliffs, NJ: Prentice-Hall.

D'Avonzo, R., Lewinski, H. and Van Wassenhove, L. (2003), "The Link between Supply Chain and Financial Performance," Supply Chain Management Review, Nov/Dec, 40- 47.

Duzakin E. and Duzakin, H. (2007), "Measuring the Performance of Manufacturing Firms with Super Slacks Based Model of Data Envelopment Analysis: An Application of 500 Major Industrial Enterprises in Turkey," European Journal of Operational Research, 182, 14121432. 
Ege, I. and Bayraktaroglu, A. (2008), "Yatırımın Nakit Akım Karlılıgı ile IMKB'de Islem Goren Isletmelerin Performanslarinın Olculmesi," Retrieved March 11, 2009, http//:www.mskongre.org/doc/ilhanege.d oc.

Ellram, L. M. and Liu, B. (2002), "The Financial Impact of Supply Management," Supply Chain Management Review, November/December, 30-37.

Farrell, M.J. (1957), "The Measurement of Productive Efficiency," Journal of the Royal Statistical Society, Series A (General), 120, 253-290.

Greenaway, D. Sousa, N. and Wakelin, K. (2004), "Do Domestic Firms Learn to Export From Multinationals?" European Journal of Political Economy, 20, 10271043.

Gunasekaran, A. Patel, C. and Tirtıroglu, E. (2001), "Performance Measures and Metrics in a Supply Chain Environment," International Journal of Operations and Production Management, 21, 71-87.

Helpman, E. Melitz, M.J. and Yeaple, S.R. (2004), "Export versus FDI with Heterogeneous Firms," American Economic Review, 94, 300-316.

Istanbul Ticaret Odası (ITO) (2006), Uluslararası Pazarlarda Turk Gida Sektorunun Rekabet Gucu ve Ihracatta Aranan Kriterler/Karsilasılan Engeller, Istanbul: Istanbul Ticaret Odası.

Liang, L. Yang, F. Cook, W. D. and Zhu, J. (2006), "DEA Models for Supply Chain Efficiency Evaluation," Annals of Operational Research, 145, 35-49.

Ling-Yee, L. and Ogunmokun, G.O. (2001), "Effect of Export Financing Resources and Supply Chain Skills on Export Competitive Advantages: Implications for Superior Export Performance," Journal of World Business, 36, 260-279.

Melitz, M. J. (2003), "The Impact of Trade on Intra-Industry Reallocations and
Aggregate Industry Productivity," Econometrica, 71, 1695-1725.

Miller, J. G. and Roth, A. V. (1994), "A Taxonomy of Manufacturing Strategies," Management Science, 40, 285-304.

Molnar, A. Xavier, G. and Kuhne, B. (2007), "Conceptual Framework for Measuring Supply Chain Performance: An Innovative Approach," International European Forum on Innovation and System Dynamics in Food Networks, 1, 261- 274.

Narasimhan, R. Kim, S. W. and Tan, K. C. (2006), "An Empirical Investigation of Supply Chain Strategy Typologies and Relationships to Performance," International Journal of Production Research, 46, 5231- 5259.

Ozdemir, E. (2009), Benchmarking the Supply Chain Performance: The Food and Beverage Industry, Unpublished Master's Thesis, Bogazici University, Istanbul.

Piercy, N. F. Kaleka, A. and Katsikeas, C. S. (1998), "Sources of Competitive Advantage in High Performing Exporting Companies," Journal of World Business, 33, 378-393.

Qu, G. Fang, Z. and Zhang, C. (2006), “A framework of Agent-Based Supply Chain Performance Analysis System," In W. Shen (Ed.), IFIP International Federation for Information Processing, 220, Information Technology for Balanced Manufacturing Systems, 57-66. Boston: Springer.

Reiner, G. and Hofmann, P. (2006), "Efficiency Analysis of Supply Chain Processes," International Journal of Production Research, 44, 5065-5087.

Ross, D.F. (1998), Competing Through Supply Chain Management, Boston, MA: Kluwer Academic Publishers.

Salomon, R. and Shaver, J. M. (2005), "Export and Domestic Sales: Their Interrelationship and Determinants," Strategic Management Journal, 26: 855871. 
Shah, J. and Singh, N. (2001),

"Benchmarking Internal Supply Chain

Performance: Development of a

Framework," The Journal of Supply Chain

Management, Winter, 37-46.

Singhal, V. R. and Hendricks, K. (2002),

"How Supply Chain Glitches Torpedo

Shareholder Value," Supply Chain

Management Review, Jan/Feb, 18-24.

Tan, K. C. Steven, B. L. Wisner, J. D. (2002),

"Supply Chain Management: a Strategic

Perspective," International Journal of Operations and Production Management, 22, 614-631.

Turk Sanayicileri ve Isadamlari Dernegi (TUSIAD) (2007, September)

Uluslararasi Rekabet Stratejileri Turkiye Gida Sanayii: TUSIAD Rekabet

Stratejileri Dizisi 10, Retrieved March 15, 2009 from

http://ref.advancity.net/En/dokumanlar/G idaRaporu_5_10_07.pdf.

Ulus, F. Kose, O. Ertek, G. and Sen, S. (2006), "Financial Benchmarking of Transportation Companies in the New York Stock Exchange (NYSE) through Data Envelopment Analysis and Visualization," Proceedings of the Fourth International Logistics and Supply Chain Congress, The Era of Collaboration through Supply Chain Networks, Izmir, Turkey, 4, 775-766.

Wong, W. P. and Wong, K. Y. (2007), "Supply Chain Performance Measurement System Using DEA Modeling," Industrial Management and Data Systems, 107, 361381.

Zou, S. and Stan, S. (1998), "The Determinants of Export Performance: A Review of the Empirical Literature Between1987 and 1997." International Marketing Review, 15, 333-356. 